\title{
The New Direction of University Library Service in the MOOC Environment
}

\author{
Xiu-li Li $1, a,{ }^{*}$ \\ JiLin Business And Technology College, ChangChun, China \\ alixiulibb@126.com
}

Key words: MOOC; University Library; Innovative Service

\begin{abstract}
This paper mainly chooses sixty normal university libraries and the needs about guokr students of three provinces in Northeast China as the research object, investigates the library to provide services for teachers and students are more innovative, somewhat different in MOOC environment, to understand the status of its service, and put forward the improvement measures to promote the development of the University Library and the MOOC.
\end{abstract}

In 2012, MOOC as "digital tsunami" swept the world, opened the door to the Ivy League university. Peking University, Fudan University, Chinese University Hong Kong, National Taiwan University and other 6 schools have joined the coursera platform in 2013. At present, 15.5 million from 162 countries students learning the EDX first course "Massachusetts circuit and Electronics", Professor Agarwal Anant, chairman of the EDX, told an interview that the chinese education is going through the historical moment of "moving the book" to "moving in the classroom". At the same time, China also launched a local MOOC - MOOC in China of netease and the higher education community to jointly launched the online education platform, she undertook the Ministry of education national boutique open curriculum task, to the public to provide Chinese famous universities MOOC curriculum; This paper surveys 60 college library resource service of MOOC in three provinces of northeast in China and students demand in guokr network, understands the needs and services of the MOOC course resources in the ordinary colleges and universities, puts forward the service strategy, improves the service direction.

\section{Questionnaire Design Content and Related Information}

This investigation uses the website survey and network interviews in two ways, the research object is the 60 general university library in the three provinces of northeast china, views the list of resources is whether a separate list of the MOOC resources or not, whether the online open class or free resources embedded in the MOOC resources, or information literacy teaching syllabus is embedded in the MOOC curriculum, in order to determine whether it provides MOOC services; Network interviews were conducted for 50 students in the school of guokr network MOOC, A total of 50 questionnaires were distributed, and 46 valid questionnaires were obtained. The investigation time was May 31, 2016.Questionnaire content is the students for the MOOC resource utilization, resource access, MOOC resource types and difficulty, the specific requirements of the library service content and service mode, etc..

\section{Survey and analysis of the MOOC Resource Service in the General University Library}

2.1 Analysis of the MOOC resources of the school library website. Survey results show that The MOOC resources listed only 8 separate schools, of which 3 in jilin province, heilongjiang 4, liaoning province 1 , and most of the schools only lists China university public class or icourse, other not listed, therefore, the quality of the MOOC related services will not be too high in the 60 universities in the northeast. The best service is in heilongjiang province, especially heilongjiang science and technology university and harbin university of commerce, and do most of the library of liaoning normal university, listed at home and abroad open class and MOOC wide resources in the 
provinces, specific see Table 1.

Table 1.The list of MOOC resources of the College Library in the three provinces of Northeast China

\begin{tabular}{|c|c|c|c|c|}
\hline School name & $\begin{array}{c}\text { Domestic } \\
\text { quantity }\end{array}$ & $\begin{array}{c}\text { Number of } \\
\text { foreign countries }\end{array}$ & Resource name & Resource content \\
\hline $\begin{array}{ll}\text { Jilin } & \text { Normal } \\
\text { University }^{[1]} & \end{array}$ & 1 & & Chinese University open class & $\begin{array}{l}\text { name+website+intr } \\
\text { oduction + subject }\end{array}$ \\
\hline Beihua University $^{[2]}$ & 1 & & China University video open class & name \\
\hline $\begin{array}{ll}\text { baicheng } & \text { normal } \\
\text { university } & \end{array}$ & 11 & & $\begin{array}{l}\text { icourse ; National Excellent } \\
\text { Course; Peking University Public }\end{array}$ & $\begin{array}{l}\text { name+website+ } \\
\text { introduction }\end{array}$ \\
\hline $\begin{array}{l}\text { Harbin University of } \\
\text { Commerce }{ }^{[4]}\end{array}$ & 7 & 5 & $\begin{array}{l}\text { MIT open class ; Open Yale } \\
\text { Courses; icourse.etc. }\end{array}$ & $\begin{array}{l}\text { name+website+intr } \\
\text { oduction }\end{array}$ \\
\hline $\begin{array}{l}\text { Heilongjiang University } \\
\text { of science and } \\
\text { technology }\end{array}$ & 15 & 8 & $\begin{array}{l}\text { Coursera ; edx ; udacity ; } \\
\text { icourse.etc. }\end{array}$ & $\begin{array}{l}\text { name+website+intr } \\
\text { oduction }\end{array}$ \\
\hline $\begin{array}{ll}\text { mudanjiang } & \text { medical } \\
\text { university }^{[6]} & \end{array}$ & 1 & & University video open class & $\begin{array}{l}\text { website } \\
\text { introduction }\end{array}$ \\
\hline $\begin{array}{l}\text { Mudanjiang } \\
\text { College }^{[7]}\end{array}$ & 10 & 3 & $\begin{array}{l}\text { Coursera; edx; udacity ; } \\
\text { xuetangx.com; icourse. etc. }\end{array}$ & $\begin{array}{l}\text { Name }+ \text { website }+ \\
\text { introduction }\end{array}$ \\
\hline $\begin{array}{ll}\text { Liaoning } & \text { Normal } \\
\text { University }^{[8]} & \end{array}$ & 28 & 64 & $\begin{array}{l}\text { Coursera; edx; udacity ; Khan } \\
\text { Academy .etc. }\end{array}$ & Name + website \\
\hline
\end{tabular}

2.2Analysis MOOC resource embedding in information literacy instruction outline. Survey results show that in the information literacy syllabus content, so far, there is no school will be MOOC resources as a teaching plan in the 60 universities, the teaching content is the introduction and teaching of traditional information, haven't advance with the times, the current teaching content is far behind the speed of updating the information content.

2.3 Special case investigation and analysis. The survey found that the best universities what on the MOOC resources and services to do is changchun normal university in these 60 universities $^{[9]}$, for example, in the introduction of domestic resources, there are three major categories of humanities, social and natural; Introduction of foreign resources is more detailed, divided into philosophy, history, economics and other disciplines, and the course is not only the name of the course, but also names and url.

\section{Investigation and Analysis on the Demand of MOOC Students to the Library}

3.1 the use of learning resources. The survey found that the MOOC students to elective courses courseware, teaching materials and teachers cited references using rate is higher, accounted for more than $55 \%$. Secondly, to study notes, compared to 43 percent, at least for review, the ratio is $16 \%$.Students get more than $83 \%$ of the resources of the channel for the MOOC platform, followed by various types of search engines and mutual aid platform, the proportion of $55 \%$ and $53 \%$, the utilization rate of the library is the lowest, only $11 \%$. The biggest discovery of this survey is to obtain and share the most important way of MOOC resources for the MOOC discussion ${ }^{[10]}$, wechat public number, qq group, etc.

3.2 Content is difficult to be easy. Research shows that nearly half of the students believe that teaching is difficult and graduation requirements lower than the traditional classroom; Specific as: $20 \%$ think are the same, but MOOC practice more; $10 \%$ think the teaching content to increase some of the school does not speak the humanities knowledge, difficulty and graduation requirements unchanged; $8 \%$ of the students think that teaching content, higher graduation requirements, $7 \%$ thinks it is a completely different two courses, thus, the students of the cognitive impression of the class is better than the traditional classroom.

3.3 Demand for Library Services. Survey found that ninety percent of respondents believe that 
the need for library services, of which seventy percent think very much", Survey found that ninety percent of respondents believe that the need for library services, of which seventy percent think "very much", especially in the MOOC learning places, information literacy, courseware download, subject navigation, textbooks and reference books, etc., and for information consulting, document delivery and other basic services demand is low, It can be seen that the MOOC of the learning staff in-depth study and self - learning is generally higher.

\section{New Direction of Library Services}

the addition of MOOC, the paper based on the book the library's traditional service is facing a huge challenge, service orientation, service content and service mode of the library are in urgent need of change. The survey for the service of the library pointed out the direction, to understand the needs of readers, in order to better meet the reader's service. Specific performance as:

4.1 Advocacy support. Although the influence of MOOC beyond the advance, but the real understanding and learning, especially to get class certificate of people is less and less, therefore, the library can use the resources advantage of the service to readers like propaganda MOOC, advocate the new learning concept. For example, the library can do some publicity posters regularly or in the wechat public number, qq group made some of the recent popular courses, In particular, the general institutions of the library, due to the quality of the reasons, many teachers did not open MOOC, only to learn other people's resources to improve their ability.

4.2 Resources and environmental support. With the development of MOOC, more and more curriculum resources are on the net, because of the limitation of the readers' retrieval level and retrieval technology, some resources can not be satisfied. The library should make use of the advantage of the resources will be on every platform and the professional quality of curriculum integration and kept in the library, readers can retrieve the required information at any time, improve the utilization of resources but also save readers time. The survey found that most students like this free online learning, but this kind of learning is the need for willpower, but also very much hope that it can provide a place to study MOOC, for example, the digital reading room or study, for the convenience of students focus on learning.

4.3 Service support. The library should try to cooperate with schools or other educational institutions which offering MOOC courses to provide professional answering questions, thesis, or course certification, which not only promotes the development of MOOC, to mobilize the enthusiasm of students, will also be combined with the library into the online and offline perfect learning, promote the long-term development of the library.

At the same time, in the creation of information retrieval class, the focus of the university library can establish MOOC information literacy class, the general university library can be opened with other educational institutions which open MOOC information literacy class. In the retrieval course appropriate to embed MOOC resources and video, so that students learn the relevant information of MOOC, to promote their MOOC learning. For example, wuhan university professor huang as the "information retrieval" has been in wuhan, east lake, xiamen huaxia college for the teaching of information retrieval course, instead of the teachers to teach.

\section{5 . Conclusion}

MOOC as the representative of the online education as a digital product of the outbreak and the speed of the fast, She has brought us great joy at the same time also greatly impact on china's traditional education, of course, also affect the traditional library services. Library as the main body of service, but also should change the management thinking and service concept, change the mode of service and content, to enhance the overall quality of librarians, effectively combine the library resources, technology and services with the MOOC, for the dual development of the library and MOOC to lay a solid foundation. 


\section{Acknowledgements}

This paper is one of the research results of "Study on the transformation of service mode of University Library under the environment of MOOC" which is Jilin Province in 2016 "13th Five-Year" key scientific research projects(Project No.: 110th, 2016); Education Science Planning Project in Jilin Province+ theory design and Practice Research of information retrieval course in Colleges and Universities under the idea of MOOC+ one of the results of GH16461 research.

\section{References}

[1] http://lib.jlnu.edu.cn/subindex.php?Classid=0705\&Upid=07.2016-5-3.

[2]http://lib.beihua.edu.cn/BeiHua_ULib/ResourcesList.html?TypeId=0a6db12c-3070-4a99-9b37-c 008a68783ca.2016-5-3.

[3] http://lib.bcsfxy.com/V9/news20151130105499550.html.2016-5-3.

[4] http://lib.hrbcu.edu.cn/gkk.html.2016-5-3.

[5] http://www.usth.edu.cn/.2015-5-4.

[6] http://www.mdjmu.cn/tsg/content/1750.html.2015-5-04.

[7] http://lib.mdjnu.cn/nr.asp?id=36\&tid=dzfw\&la=Layer3.2015-5-04 .

[8] http://www.lib.lnnu.edu.cn/newsinfo?id=333\&cid=57.2015-5-04.

[9] http://www.edu.cn/html/opencourse/index.shtml.2015-5-04.

[10] http://MOOC.guokr.com/.2016-5-31. 